\title{
Social Capital Function Of Community Of Tuban Literacy For Collective Action Building Cultural Literacy In Tuban District
}

\author{
Afdolu Nasikin \\ Universitas Negeri Surabaya \\ afdolunas21@gmail.com
}

\begin{abstract}
The low literacy culture is a problem that should be our responsibility. Thus, the solution is not only based on formal education, but also paying attention to environmental factors. Because the environment is one of the factors that influence society's habits or interests. So literacy-based social movements should be considered. This study aims to examine the social capital in community of Tuban Literacy and its function to collective action taken to build a youth reading culture in Tuban district. This research takes case study to community of Tuban Literacy. Community Tuban Literacy is a youth community that is engaged to cultivate youth literacy culture in Tuban district. The methodology used in this study is qualitative design with data collection method through observations and in-depth interviews that aim to obtain specific data related to social capital and collective action process undertaken by community Tuban Literacy. Based on the analysis, the social capital of community of Tuban Literacy has a significant effect on collective action. The collective action in the form of activities is Lapak Baca, Tadarus Books, Nggacor sak mbledose, Tour to School, Writing Competition, Cangkruk'an Literacy, Ngamen Literacy, Reading Tree, and Pesantren Literacy. These activities are able to attract teenagers to participate in every community of Tuban Literacy activity. The average ability of young people to read in the community of Tuban Literacy is at the level of literacy. Thus, the output produced is a lot of teenagers whose intensity of reading increases and leads to critical thinking.
\end{abstract}

Keywords-Community, Social Capital, Collective Action, Literacy Culture

\section{INTRODUCTION}

Literacy in Indonesia is currently experiencing a very poor condition, in terms of reading interest community, Indonesia is still considered very low. Indonesia's position is at number sixty of 61 countries based on the nation's literacy cultural rankings released by Central Connecticus State University (CCSU) on March 09, 2016 (CCSU, 2016, March 9). Indonesian literacy culture is still low compared to Asian countries such as South Korea, Japan, Singapore, China, Malaysia, and Thailand. But surprisingly, during the year 2016, 132.7 million Indonesians are connected to the inter net, a very rapid development from the period since 2014 which was only 88 million people (APJII, 2016, November
5). The rapid development is not comparable with the literacy culture of Indonesian society is still very low. The easy access of internet network has not been useful to support literasi culture in Indonesia. Some other countries are also experiencing similar problems. Based on the analysis of Sonali, Snowling \& \& Asfaha (2016) that, low literacy culture occurs in low and middle-income countries such as Eritrea, Ethiopia, Ghana, India, Kenya, Mauritius, Mexico, Pakistan, Peru, South Africa, Tanzania. They added that the literacy form in these countries from 1990 to 2014 is still limited to reading in the classroom, yet has not led to the students critical power and immediate application. The reading culture of Indonesian youth is still low (Setiawan, 2016; Siswati, 2010; Triatma, 2016; Farida, 2012; Shofatussamawati, 2014; Permatasari, 2015; Aprilia, 2016). The low reading culture is caused by environmental influences, entertainment, oral culture, and economic factors (Triatma, 2016; Farida, 2012; Shofatussamawati, 2014; Permatasari, 2015; Aprilia, 2016).

Literacy in Indonesia is currently experiencing a very poor condition, in terms of reading interest community, Indonesia is still considered very low. Indonesia's position is at number sixty of 61 countries based on the nation's literacy cultural rankings released by Central Connecticus State University (CCSU) on March 09, 2016 (CCSU, 2016, March 9). Indonesian literacy culture is still low compared to Asian countries such as South Korea, Japan, Singapore, China, Malaysia, and Thailand. But surprisingly, during the year 2016, 132.7 million Indonesians are connected to the internet, a very rapid development from the period since 2014 which was only 88 million people (APJII, 2016, November 5). The rapid development is not comparable with the literacy culture of Indonesian society is still very low. The easy access of internet network has not been useful to support literasi culture in Indonesia. Some other countries are also experiencing similar problems. Based on the analysis of Sonali, Snowling \& \& Asfaha (2016) that, low literacy culture occurs in low and middle-income countries such as Eritrea, Ethiopia, Ghana, India, Kenya, Mauritius, Mexico, Pakistan, Peru, South Africa, Tanzania. They added that the literacy form in these countries from 1990 to 2014 is still limited to reading in the classroom, yet has not led to the students critical power and immediate application. The 
reading culture of Indonesian youth is still low (Setiawan, 2016; Siswati, 2010; Triatma, 2016; Farida, 2012; Shofatussamawati, 2014; Permatasari, 2015; Aprilia, 2016). The low reading culture is caused by environmental influences, entertainment, oral culture, and economic factors (Triatma, 2016; Farida, 2012; Shofatussamawati, 2014; Permatasari, 2015; Aprilia, 2016).

Research from Dadang Setiawan (2016) on Students SMPN 3 Sewon Bantul, want to know the social support of parents to student reading interest. Using descriptive qualitative research methods. The results reveal that there is some parental social support in the form of emotional support, ins-trumental, informative, and reward, but the most dominant is emotional support. However, on the field, Dadang found the phenomenon that children tend to prefer to watch TV and play games and play with friends rather than reading books. Unlike Siswati's research (2010), the focus is on reading interest of students in the first semester. The research method used is a descriptive survey involving 92 students in the first semester. The results showed that $54,4 \%$ of students read for one hour a day and $52.2 \%$ for five hours in a week, and the kind of reading the novel more dominant. The habit of playing online games and watching TV is still a barrier of interest in reading students. The literacy culture still needs to be improved and it takes strategies to create a culture of literacy in society (Halbert \& Chigeza, 2015; Kamalova \& Koletvinova, 2016; Kavi et al., 2015; Sonali et al., 2016; Hui \& Cheung, 2015)

Some of the above studies show that the cultural literacy of adolescents and the community is still low. There are many factors that cause low literacy culture, as described above. However, the environmental conditions are the main cause, so it needs to create a new environment to preserve the culture of literacy. As explained by Hernowo (2002) that someone who likes to read is brought up from a reading love environment. The immediate environment is what will affect a person to get closer to the reading. So someone does not like to read because since childhood was raised by parents who never get closer to the reading.

The rapid development of technology brings both the impact of positive and negative on humans in the modern era. So that technology users should be able to take advantage of as possible as needed. Cannot be denied, Television also affects the low culture of literacy, especially at the age of children. The comparison of watching television is longer than reading a book, such as the findings of Kavi \& Bugyei (2015), in his research at Andrine Aglican Andrew Sr. junior school in the city of Sekondi Ghana, that the majority of respondents involved read only when facing exams, while self-development as well as digging information through reading still low. Their most serious disadvantage is the habit of watching television. Indonesia also experienced the same thing that the habit of watching television is still a culture that beats the culture of reading, let alone entertainment films are still a pretty high attraction, seen when there is a new movie release. The high interest in watching Indonesian television was released by the Central Bureau of Statistics in 2015, which reached $91.47 \%$ for the age category of 10 years and above (BPS, 2015).

Indonesian literacy culture still needs more attention, because speech culture (oral) is more dominant than reading culture. This culture becomes an obstacle to increasing the quality of community resources and knowledge independently through reading (Tilaar, 2002). Some studies reveal various obstacles and efforts made to develop a culture of literacy, some solutions are also offered in research through mentoring reading culture in schools (Fahrurrozi, 2015), increasing facilities / facilities to support literacy culture (Permatasari, 2015), strengthening school management (Widyaningrum, 2016), the role of the family (Tanjung, 2016). Other studies have also revealed efforts to develop literacy culture through a program approach. For example, research from Carron, Mwiria, \& Righa (1989), a study of the impact of the national literacy program in Kenya, the comparison of literacy graduates (people who obtained literacy certificates) with people not literacy. The study is based on structured response items and finds that literacy is much better than non-literacy in political knowledge (eg, identification of ruling political parties and election comprehension) and political behavior (participation in elections and members of local associations). The evaluation of the national literacy program in Uganda (CarrHill, 2001) also compares people who are aware of literacy with unconscious literacy. the study found that literate people (women and men) tend to favor less patriarchal attitudes, such as refusing domestic violence, sharing domestic duties, women as good village leaders, and women's right to maintain their own income. Carr-Hill's study offers a correlation between attitude and behavior. When asked about actual practice, newly literate women show little change in parenting responsibilities, but the strong distinction with literate people is to keep their income.

Another An ethnography study by Prins (2008), about the literacy program in El Salvador. His research found that women and men report changes toward greater selfconfidence, self-esteem, ability to participate and influence in new spaces, the ability to formulate and express ideas, and improve relationships with partners, parents, children children, or other family members. However, the collective form of empowerment is not observed. Prins attributes the short duration of the program with the fragmentation of the nature of Salvadoran society after the civil war.

Some of these studies prove that the level of literacy ability of society affects social behavior, politics, economy, and critical power. So that the culture of literacy should be developed to lead a society that is highly civilized. In addition to the above approaches, there is another approach that can be used as an alternative is the empowerment approach. As Sholkamy suggested (Anna Robinson, 2014) that, we must cultivate literacy through the idea of empowerment mechanisms. Sholkamy exemplifies the empowerment of women for a better understanding of their policies and practices, since statistically speaking, literate women are very influential on the participation of decisionmaking and economic policy rather than ethnographic insights on how women's lives and identity changes. Sholkamy also suggests national and local-level critical literacy education programs.

This research offers literacy culture development solution through community group movement. The existence of community groups that develop a culture of literacy can have an impact on environmental change. Because, community groups (Communities) have the power of social capital to take collective action. If the cultural development of literacy is done by collective action by community groups, then the role has a positive impact on the culture of literacy. so, we must know the social capital and its function in the 
community (community) group. Social capital is seen as one element of community capacity to carry out collective action (Pinto, 2006). Studies of social capital explain the fundamental understanding that social capital is a manifestation of the characteristics shown by social organization, such as the existence of networks, norms and beliefs that facilitate coordination and co-operation in an action for the benefit of many people (Bourdieu, 1986) . According to Dahal and Adhikari (2008), social capital becomes a discussion in collective action studies because Putnam (1993) associates that the association patterns formed by social capital are the solution to the difficulties faced by communities in collective action.

All communities have the capacity and social capital of each. Chaskin (2001) argues that community capacity is the product of the interaction of human capital, organizational resources, and social capital owned by communities that can influence collective problem-solving, enhancing and maintaining the welfare of communities. A community is also dynamic, so the capacity of a community can also change. According to Chaskin (2001), several factors affecting the capacity of the community are 1) The existence of resources ranging from the expertise of each individual to the strength of the organization in accessing financial resources, 2) the relationship network, 3) leadership, 4) support for movement where every member of the community can participate in collective action and problem solving. Furthermore, Chaskin (2001) identifies the characteristics of community capacity as follows: 1) Community sense, 2) Commitment, 3) Ability to resolve problems, 4) Access to resources.

Community organizing is one of the ways needed to improve the social capacity of a community. According to Sinclair (2006), com-munity organizing offers social transformation as follows: 1) Motivate the community to take action in harmony with their values and beliefs, 2) Link community with passion and acknowledge the generative power of anger, 3) accommodate the same goal into a joint struggle. According to Stall and Stoecker (1998), community organizing is a com-munity building process that can be mobilized. This includes building people networks, identifying shared expectations, and who can engage in actions or social actions to achieve those shared ideals. Community organizing refers to the whole process of organizing relationships, identifying issues, mobilizing people for the issue, and maintaining and maintaining the organization. Community organizing is also a process of building forces that involve people in defining the problems of a community, defining the issues to be solved, the solutions raised, and the methods used to solve the community's problems.

Social capital as a reference quality of the relationship of a group, community, organization, and society. Social capital is a resource that is seen as an investment to acquire new resources. Social capital is not defined as matter, but social capital is found in a person. Social capital is more emphasis on the potential of groups and patterns of relationships between individuals in a group and between groups. Social capital existing in a group can determine the survival and functioning of a group. According to Bourdieu (1986), Social capitalis the aggregate of the actual or potential resources which are linked to possession of a durable network of more or less institutionalized relationships of mutual acquaintance and recognition or in other words, to membership in a group. Based on Bourdieu's view that social capital is a whole resource associated with the ownership of a permanent network of institutional relations and is based on mutual recognition and mutual recognition. Thus, members of a group will gain support from collectively owned capital. Bourdieu further argues that the volume of social capital held by individuals in a group depends on how far the quantity and quality of the network of relationships it creates. In addition, how much volume of economic, cultural and social capital owned by each individual in the group. Meanwhile, Coleman in his writings entitled "Social Capital in the Creation of Human Capital" (1988) introduces social capital as a conceptual means for understanding the theoretical orientation of social action by linking the components from a sociological and economic perspective. Based on this method, he uses principles in economics to analyze social processes. Coleman discusses how social capital is formed and highlights social capital in three different forms: First, obligations and expectations arising from a sense of trust in the social environment. Second, the importance of a smooth flow of information within the social structure to encourage the development of activities within the community. Third, norms that must be obeyed with clear and effective sanctions. However, Putnam (1993) divides the three elements in social capital are norms, networks, and beliefs.

The existence of social capital within community groups (Communities) will encourage collective action. Collective action will occur if more than one individual is required to contribute towards an endeavor to achieve a common purpose (Ostrom, 2002). Marshall (1998) defines collective action as an action by a group (whether with or without an organization) to share common interests. The daily life of society is inherent in collective actions, every time man will always produce and consume something that is public or collective. Explaining the concept of collective action is still a challenge in the science-social science to date. In its development, many theoretical models are intended to illustrate how collective action in society can take place. According to Olson (2001), one of the first figures to introduce the concept of collective action states that important determinants for the success of a collective action are size, homogeneity and purpose of the groups. Olson further explained that a collective action will work optimally depending on the three determinants. Hypothetically, the larger the size of a group of interests it will be more difficult for the group to negotiate the interests among the members, and vice versa. that groups built with small sizes will work more effectively.

The rationale for choosing collective action is based on the economic rationalist and communicative rationalist. Olson (1965) in his book The Logic of Collective Action argues that the view of a group acting to meet the collective needs of its members begins with the assumption that the individuals in the group want to meet their self-interest. Olson is one of those who developed the theory of the collective action of economic perspective, so the concept of collective action is still seen from the standpoint of economic rationalist, that man will seek economic gain during his life. Thus, Olson (1965) stresses that although a group of people take collective action, its orientation is certainly the wellbeing of the individual. Thus, the rational choice to choose the collective action first introduced by Olson is logically following personal interests. Collective action is done 
because there is a common goal and that goal will be absolute if done with collective action. The theory of Olson is known by the term "zero contribution thesis" which reads: "Unless the number of individuals in a group is quite small, or unless there is coercion or some other special device to make individuals act in their common or group interest, rational, selfinterested individuals will not act to achieve their common or group interest"

The essence of the Theory is that collective action will be accomplished if a goal is achieved by collective action based on rules and voluntary. Collective action can fail because of egoist rationalist and free rider. Along with the development of the theory, Miller (2014) argues that Olson's theory has ignored the importance of interaction factors that shape individual behavior to create social bonds within communities as factors that can influence collective action. For example, as Jencks (1979) has criticized Olson's (1965) assumption that socially rational human beings must have sympathy, commitment, empathy, and morals that influence decision-making when taking collective action. Miller (2014) argues that the theory introduced by Olson is too assumed that man has a manipulative nature.

Habermas (1984) in The Theory of Communicative Action separates collective actions based on social and nonsocial situations on the desired orientation such as the table below:

Table 1. Collective action based on the orientation to be achieved

\begin{tabular}{ccc}
\hline $\begin{array}{c}\text { Action } \\
\text { Orientation }\end{array}$ & $\begin{array}{c}\text { Oriented to } \\
\text { succes }\end{array}$ & $\begin{array}{c}\text { Oriented to } \\
\text { reaching } \\
\text { understanding }\end{array}$ \\
\hline Situation & Instrumental \\
Nonsocial & Strategic & \\
social & action & Communicative \\
& action \\
\hline
\end{tabular}

Source : Habermas, 1984

Miller (2014) argues that communicative action in the collective action of Habermas is the most rational approach to seeing its practice. Referring to the community theory of Calhoun (1988), a group acting on collective action, instinctively will form cohesiveness within the group. Communicative rationalist in collective action essentially recognizes that individuals always interpret their social circumstances by communicating and interacting with other individuals. This process of communication and interaction has an effect on the ongoing collective action. Communication and interaction become elements of social bonding stabilization.

The difference between a communicative rationalist and an economic rationalist is about the existence of a freerider (an individual who does not contribute anything in collective action). Communicative rationalists allow for a freerider and view the individual not as a problem. Essentially, if they are carrying out collective actions are only partially called organizing in the community, they are considered to be fine, as long as the interests of their members are kept intact (Miller, 2014)
Meinzen-Dick (2004) argues that any action taken collectively has a decisive factor in its success, because it leads to the success or failure of the achievement of the action. Collective action will usually be maintained. For example a group performs a series of actions for a purpose, but the first time the result is not as expected, then another action will be taken as an improvement from a previous set of actions. The process flow can be seen in the picture below:

Figure 2.1. Process Flow of Collective Action

\begin{tabular}{|c|c|c|c|}
\hline & Structure & Collective & Outcomes \\
\hline $\begin{array}{c}\text { Determining } \\
\text { Variables }\end{array}$ & $\begin{array}{c}\text { of } \\
\text { entities }\end{array}$ & Action & \\
\hline
\end{tabular}

\begin{tabular}{ccc}
\hline Structure & Conduct & Performance \\
\hline \hline
\end{tabular}

Source: Meinzen-Dick (2004)

Determining variables or factors affecting the implementation of collective action are learned from the revisions of what action a group does when its actions are deemed unsuccessful. Agrawal (2001) classifies these factors into; (1) Resource Characteristics, (2) Group Characteristics, (3) Institutional arrangements, (4) external factors of the environment / situation.

This case study takes the subject of research on the community of Tuban Literacy located in Tuban district. The community is interesting to study because of consistent social movements to cultivate literacy in Tuban district. This research will reveal how they maintain their existence with existing social capital and their function in the collective action of developing a literacy culture in Tuban district.

\section{RESERACH METHOD}

This research uses qualitative design with case study method. According to Robert K. Yin, the case study refers to research that has elements of how and why on the main questions of his research and examines contemporary issues and at least the chances of the researcher in controlling the cases studied (Yin, 2008). The purpose of qualitative research is to understand the phenomenon of what the subjects of research experience, such as behavior, perception, motivation, action, etc., holistically, and describe in the form of words and language, to a specific, natural context and utilize various natural methods (Moleong, 2007). This study aims to obtain a holistic and holistic description of social social capital and its function towards collective action to improve literacy culture in Tuban Regency. Selection of research subjects using snow ball sampling technique and purposive sampling. While the method of data collection using observation, in-depth interviews, and documentation. According to John W. Creswell, researchers can conduct face-to-face interviews with participants, telephone interviews, or engage in focus group interviews consisting of six to eight participants per group (Creswell, 2009). The technique of data validity to be used is triangulation technique and member checking. In this step will be checked back validity or validity of data findings as an effort to check 
the accuracy of research results by implementing certain procedures or strategies (Creswell, 2009).

\section{RESULT AND DISCUSSION}

\section{A. The Social Capital of Community of Tuban Literacy}

The community of Tuban Literasi is a non-structural group with an independent, voluntary, networking and dynamic activity management model. Community of Tuban Literacy is sustained by participatory action and involves networking to strengthen its movement. This shows that the community of Tuban Literasi as part of community participation on the provision of non-commercial public education space related to knowledge access. Such collective action cannot be separated from the role of every member involved because individuals in the community become the spearhead of the existence of community of Tuban Literasi. Patterns of relationships, cooperation, and mutuality among members also affect the success rate of the collective actions they undertake. This can be seen from the social capital in it. There are three basic elements of social capital according to Robert Putnam (Field, 2011) is trust, network, and norm. These three elements form the basis of the analysis of social capital in the community of Tuban Literasi.

\section{Norm}

Norms are conditions governing social life. In general, norms apply universally, but can also apply in a particular environment. Norms that apply in the community, will certainly affect the environment in the community or group. According Soerjono Soekanto (2010), the level of norms can be categorized from the weakest to the binding based on the way, custom, behavior, and customs. Based on observations, the norms prevailing in the community of Tuban Literasi are influenced by the norms in society such as mutual respect, courtesy, and commitment. Mutual respect: although the Tuban Litetation community is heterogeneous, they remain mutually respectful, such as differences in the background of beliefs, particular mass organizations, and education levels. Courtesy: like the event done in the pesantren, the clothes used adjust the customs of the courtesy of the pesantren. In other activities, if there is one member who wants to smoke during the discussion, they will stay away from the female participants. There is also one member who reprimands "Cocote cah" (Mouth). Commitment: they must ask or insinuate friends if they are not present at the event, even if only to say "iyo, wong penting, makane jarang teko" (basic people busy, then rarely present), or when someone borrows books, but not returned on time as determined, they will be the talk of other members. Based on the research subject's statement, there are rules agreed upon by members of the community of Tuban Literacy to avoid political agendas, not tied to any institution, not seeking material benefits, and not aiming for a particular ideology.

Norma is very important existence in the community. If in the community there are no certain norms that apply then there will be problems. According to Francis Fukuyama (2005), there are some problems that will arise if there is no norm in the community. The problem is that moral values and social rules are not merely arbitrary constraints on individual choice, but vice versa. That is the prerequisite of various cooperation. Then, will the community end, if the rules or social norms do not exist.

The community of Tuban Literacy is open to anyone who wants to join. They open the network as far as possible. They network with all parties, individually or in groups who can be invited to work together to develop a culture of literacy. As informed by respondents that resource mobilization has been done by community of Tuban Literasi through various ways such as, socialization through media information, tour to school, competitions, discussion, bookshelf, and other activity. These activities were conducted to attract communities in Tuban district. The spirit of fight for in the analysis of social capital type, Robert Putnam called Bridging Social Capital. Simply put, the social capital form of the community of Tuban Literasi is illustrated in the table below.

\section{Trust}

Trust is one important element of the social capital of the community so that the intensity of collective action is maintained. As research conducted by Asriwandari (2016), Dwiyantari \& Kaligis (2015), Syawie (2007) that, trust has an important influence on the intensity of the community. However, this study explores more specifically the cause of growing trust among members of the community of Tuban Literacy. Trust in the Tuban community Literacy grows on the basis of reliability and closeness among members. The reliability of members of the community of Tuban Literacy is evident from the active participation of each activity, as well as the mutual response to the activity agenda. It is this response that triggers the mutuality between individuals, so it appears to trust each other. According to (Castiglione, 2007), trust with the model is called strategic trust. They take action that should be done by members of the community that plays an active role in developing the community with access and ideas that they have.

In addition, trust among members of the community of Tuban Literasi grows on the basis of the resources owned by each member. Seen the names listed on the stewardship structure is Amrullah served in the field of information and communication because it has the ability of journalism and communication science. Ahmad Dafit served in the field of study \& discussion because of the wide insight and graduates of philosophy. Wahyu Eka Setiawan in the field of authorship for having good writing skills. Such strategic beliefs to encourage one of the realizations of their collective action. However, the longstanding relationship of friendship also becomes their basis for mutual trust because it already knows the character of each.

Tuban Community Literacy always make efforts to maintain solidarity among community members through social contact, communication, and loyalty among the members. Efforts made by community of Tuban Literasi such as dolen (play), bakaran (cooking), coffee (hanging out). Although simple, but has an impact on the close relationship of each member of the community. The 
findings indicate that the community of Tuban Literasi has met the criteria as a social group as Sukarno said. Soekanto (2012) says, human unity cannot be called a social group if it does not meet some criteria such as conscious as part of a group, there is a reciprocal relationship, has the same interests and has a pattern of behavior.

\section{Network}

Based on observations and interviews, the network between several individuals within the internal group has been formed since before the group community was formed. The long-standing intensity of communication fosters social ties between them. Thus, their social ties are very strong (strong ties). According to Field (2011), people build relationships through a series of networks and they tend to have shared values with other members of the network. As long as the network becomes a resource, it can be viewed as capital. The Field Statement provides an overview of social capital that, networking is quite influential on cooperation and relationships between individuals, individuals with groups, or groups with groups. This established network generates a shared commitment to build literacy culture of reading through the established community of Tuban Literacy. Plus new networks after the formation of community of Tuban Literasi that provides resources support in the community.

Networks built within the community of Tuban Literacy encourage the emergence of trust among members. Mutual trust between members of the community of Tuban Literacy because of the intimacy between them. In addition, they have a sense of responsibility for the initial commitment they have agreed upon. Proven, their involvement not only as active participants, but also participate in planning each activity. Start building vision, activity ideas, and evaluation. Their trust is demonstrated by their involvement in managing the community. Unlike members who are passive, they are only limited to participate when there are certain events or events. So that their social ties with other members are still weak (weak ties).

The statement refers to the Strength Of weak ties theory developed by Granovetter in social network analysis. According to Granovetter (1983), the Strength Of Weak Ties theory consists of two bonds namely, strong bonds and weak bonds. A strong bond is a combination of the amount of time, emotional intensity, proximity (mutual trust), and unrequited service which form the character of the bond. While the weak bond is the bond between the personal with a closeness that is not so intimate, can also be called as an acquaintance.

In addition to the internal network, community of Tuban Literasi also extends its network in various groups, individuals, and institutions that can be reached. This is done to expand the movement and attract many resources that can participate in the development of literacy culture of reading in Tuban district. This network is visible on networks owned by the community. Based on the results of interviews, the community of Tuban Literasi has many networks such as information media, community groups, students, regional libraries, teachers, lecturers, government institutions, school institutions, universities, pesantren, writers, etc., which can be utilized for the development of literacy culture.

A series of networks owned by informants (members of the community of Tuban Literacy) are resources that can support the development of literacy reading culture in Tuban district. The networks of friends, students, students who are on average owned by the informants above will be new participants or members of the community. This network is more personal that can be invited to participate in every community agenda. Unlike the networks to institutions, communities, mass organizations, and media owned by some of these informants who can support and cooperation to develop a culture of literacy.

They take advantage of their owned networks to support their movement and activities undertaken by the community of Tuban Literasi. Examples of such network functions are seen in new members who participate in participating. Most of the new members who participated because there are friends who invite. Another example, the function of networks on activities ever undertaken by the community of Tuban Literasi is a writing and bookwriting contest involving schools, institutions, and community groups. The function of the network to this activity becomes important because it requires access to any other institution or group that can support the activity.

\section{B. Collective Action of the Community of Tuban Literacy in Building a Reading Culture for young people}

The existence of a community depends on the voluntary community members and also the leadership in the community. There are several communities that do not develop because fellow members do not have good communication or not devote time and effort to the development of the community itself (Wenger, 2002). Community is a part of society that shares information about a particular subject. They discuss their circumstances, aspirations and needs (Wenger, 2002). This also happens in the Tuban Literacy community. They always share ideas and ideas related to the literacy movement they will do.

Environment is one factor that influences children's habits or interests. As expressed by Zakaria Drajat (2001), children's interest can arise from various sources, including the development of instincts, intellectual functions, environmental influences, experiences, habits and education. Another Hernowo (2002), said someone who likes reading is raised in an environment that loves reading. Actions taken by the Tuban Literacy community also intend to create an environment that loves reading. Based on this, this research was conducted to determine the function of social capital towards the collective action of the Tuban Literacy community.

Community of Tuban Literacy purely social movement that emerged from the public. They voluntarily develop a culture of literacy with the resources they have. The vision and mission are built is a form of social concern towards the development of a culture of reading society in Tuban. Jencks (1979) says that humans are rational socially certainly have sympathy, commitment, empathy, and moral influence in the decision when making collective action. Similarly, the action 
taken community of Tuban Literacy, the reason they form a community not-for-profit private matter and needs, but as a means to learn and develop a culture of reading.

There are two rational reasons humans choose collective action. First, economically oriented. In Olson's view (1965) that, although a group of people act collectively, their orientation is certainly the welfare of the individual. Olson's view is based on an economic perspective. Thus, the concept of collective action is viewed from an economic rationalist point of view and personal welfare. Second, social oriented. Jencks (1979) expressed criticism of the views of Olson's collective action that socially rational human beings must have sympathy, commitment, empathy, and morale that influence decision making during collective action. Olson's view above is not proven in the Tuban Literacy community. All forms of activities carried out by the Tuban community Literacy are not materially beneficial. They carry out collective actions based on morality, sympathy and commitment. They sacrifice energy, thought and funds to succeed in an activity.

The collective action of the community of Tuban Literacy begins with mass mobilization. Mass mobilization was carried out by inviting schools, campuses, communities, regional student organi-zations, several community leaders to attend the declaration of the formation of the community of Tuban Literacy. The declaration was made to introduce the community of Tuban Literacy to the community and invite them to participate in building a reading culture. Through the declaration, the community of Tuban Literacy formed a structure in the form of coordinators in each sub-district. The effort to expand the network in each of these sub-districts is done to facilitate coordination and expand the movement. However, this action was deemed unsuccessful because not all coordinators went well. Nevertheless, there is still potential to be developed in two villages, the kerek and singgahan villages. Through village youth and youth groups, the community of Tuban Literasi formed a village library managed by youth organizations. Then, Tour activities to the Literacy School and Pesantren. This effort is carried out as a literacy campaign strategy, socialization and attract students interest. They use networks or access to schools to mobilize new resources from students and teachers. Unlike the Pesantren Literacy, this activity can only be done at the pesantren because the students activities are limited by the pesantren rules. Based on the analysis, some of these actions are evaluations of the collective action of the community of Tuban Literacy.

Community of Tuban Literacy activities prepared and packaged in various forms of such activities,StallsRead, Tadarus Books, Cangkruk'an Literacy, Nggacor sak mbledose and Writing Compe-tition. Stalls Read the provision of reading activities for the community. This activity is carried out every Sunday in the courtyard gymnasium Tuban. Sports hall yard haunts Tuban are young children and the location of the car free day on every day of the week. Reading begins with the reading by members of the community to attract other young children around. This activity has triggered action local library to do the same. These findings demonstrate the functioning of the social capital of the community of Tuban Literacy collective action read. While this step produces a small output,

Sulistyo (1991), distinguishes seven levels of reading ability: (1) people who are unable to read at all; (2) people who have limited ability to read; (3) people who are learning to read; (4) people who are literate, but do not read unless reading reading is limited to everyday life; (5) people who are literate, but not book readers; (6) people who are literate, but not permanent readers; (7) literate people and permanent book readers.

The strategy of developing youth reading culture conducted by the community of Tuban Literacy is not just limited to reading. There are other activities that trigger critical thinking that is Tadarus Books, Cangkruk'an Literacy,and Nggacor sak mbledose. Tadarus Books is a book review or discussion about the contents of the book. Usually, this type of book is offered to participants before the activity is carried out. Meanwhile, Cangkruk'an Literasi is an informal activity or hanging out by inviting certain speakers, according to the theme to be discussed. They use their network to invite speakers. The characters they invite are people who have the capacity in a particular field. Some of the figures they had invited to become speakers were Authors, TV journalists, editors of Radar Bojonegoro, Soesilo Tour, and Lecturers. Invited figures are used as a group to attract young people.

The output power of reading fosters critical thinking society. Through Nggacor sak mbledose, participants are expected to have a sensitivity to the environment. Nggacor Sak mbledose an activity of critical thinking through discussion place to hang out. In general, Community of Tuban Literacy has the same habits with other communities such as cangkruk / coffee (hang) and gathered at certain days. However, it has the characteristics hanging habit and conceptualized. Although only seen hanging like in general, the theme has been put up as a chat in a coffee shop. Typically, the themes are made regarding the condition of educational, economic, social, local culture district of Tuban. Some examples of themes that have been discussed is the problem of the tradition of drinking drinks (liquor), chicken gambling, infrastructure development, the impact of cement and oil companies on the environment and society, the policies of the regent, water scarcity, thuggery in the pedicab driver, etc.

Other activities that have been done by the community of Tuban Literacy is competition wrote to the Regent and the potential of the village. This movement is an effort to trigger the collective action of young people through writing. Through the writing competition, the public can express their aspirations to inform local authorities and potential that exist in the village. Posts competitors WEB published in the community and some published in the press.

Activities that have been carried out by the community of Tuban Literacy is a strategic action and a form of evaluation of previous activities to achieve the expected goals. This is done to make activities more interesting than before and adjust environmental conditions. This collective action proves the existence of an element of social capital capacity which includes networks, norms and beliefs in the community of Tuban Literacy. However, this collective action is influenced by the characteristics of the community of Tuban Literacy.

Quantitatively, the membership of the community of Tuban Literacy is divided into three. First, active members, are members who actively participate in activities and take part in thinking about activities concepts. Second, passive 
members, they are called free-rider. They are individuals who do not contribute to collective action. In addition, there were participants, their numbers were always changing, so it was difficult to measure how many young people participated in each activity. According to the subject of the research, the participation of young people are increasing compared to the beginning of the formation of the community. Indeed, the existence of the membership of the community of Tuban Literacy is evident in the active members. They have an important role in community development. So, for them, maintaining relationships is something that is very important to maintain.

\section{The reading culture of young people in the community of Tuban Literacy}

One factor that influences the growth of reading culture is the social environment. Like Zakaria's (2001) statement, interest can arise from various sources including instinct development, intellectual functions, environmental influences, experience, habits and education. Meanwhile, according to Farida (2008), there are several factors that influence interest and ability to read, namely, physiological factors, intellectual factors, environmental factors, and psychological factors. Therefore, someone's interest must be fostered and directed to achieve the desired goals.

The direction of the community of Tuban Literacy movement in developing the reading culture of teenagers in Tuban uses environmental factors. So, they take collective action to attract teenagers in Tuban to join the community that can create an environment for teenagers who love reading. This is very influential for adolescents in the community of Tuban Literacy. There are differences in the intensity of reading youth in Tuban before and after they often gather with community members. They often do reading habits because they are influenced by activities in the community that often carry out reading literacy activities such as tadarus Books, nggacor sak mbledose, Cangkruk'an literacy, and reading stalls. Some of these activities are routine activities of the Tuban Literacy community.

Many strategies are carried out to develop a youth reading culture. Some studies also showed positive results on methods of developing reading culture such as communitybased literacy movements that involve rural communities (Yanto, Rodiah\&Lusiana, 2016), village literacy programs (Suharyan\&Tamba, 2017), creating community reading parks ( Darmawan, 2016; Sani\&Suwanto, 2018). However, the method of developing the reading culture is limited to a small scope in certain villages. There are differences in strategies carried out by the community of Tuban Literasi to attract more participants in a broad scope through networks such as schools, groups / communities, youth clubs, cafes or youth places, and networks of friends. They focus on teenagers in Tuban regency who are not limited to certain villages.

On average, the reading ability of teenagers in the community of Tuban Literacy is at the level of literacy. Sulistyo (1991), distinguishes seven levels of reading ability that is (1) people who are unable to read at all; (2) people who have limited reading ability; (3) people who are learning to read; (4) people who are literate, but do not read unless reading reading is limited to everyday life; (5) literate people, but not book readers; (6) people who are literate, but not permanent readers; (7) literate people, as well as permanent book readers.

Tadarus Books activities, Cangkruk'an Literasi, Nggacor sak mbledose, and writing competitions by the community of Tuban Literasi, indirectly they have made efforts to foster critical thinking because these activities can only be followed by literate children. Through Tadarus Books, there is a process of learning, thinking, studying, and analyzing combined with empirical data. The books that were discussed in various titles about the environment, social, education, agriculture, economics and politics. Hidayat (2013) said, critical education as a social education movement that aims to realize the implementation of education that is egalitarian, humanist, democratic based on critical awareness. Critical awareness is not only in the form of cognitive aspects, but also in the form of actions. There is no teacher and student learning process in the Tuban Literacy community, they exchange ideas with each other's knowledge. Meanwhile, the writing competition is a practical action that aims for young people to express their aspirations and the potential of the village on the basis of their critical power.

There are several assumptions about the basic philosophy of critical education. That is human beings have the capacity to change and develop because they have the potential to learn and think. Humans have an ontological and historical calling to become a more perfect human being. Humans according to Colin Lanskhear are praxis beings who live authentically only when involved in world transformation (Nuryatno, 2011).

\section{CONCLUSSION}

This study is basically constructing a process of developing the culture of reading youth by the Tuban Literacy community. During the past four years, the community of Tuban Literacy still exists in routine and conditional activities. Their intensity in carrying out these actions cannot be separated from solidarity among their members. Based on the results of the analysis, social capital has a significant influence on the social ties and solidarity of the community of Tuban Literacy. Social capital is in the form of mutual trust, responsibility, mutual respect, commitment and a sense of belonging to the community. Referring to Robert Putnam's social capital theory, the community of Tuban Literacy fulfills three elements of social capital which include, norms, beliefs, and networks.

Social capital in the Tuban Literacy community has a strategic function that can support collective action to build a sustainable reading culture. The collective action of the Tuban community is tangible literacy in a variety of actions. That is the process of forming a community, formulating a vision and strategy, mobilizing resources, until the implementation of activities has been carried out. The activities carried out were Lapak Baca, Tadarus Books, Nggacor sak mbledose, Tour to School, Writing Contest, Cangkruk'an Literacy, Ngamen Literacy, Reading Tree, and Pesantren Literacy. Some of the outputs produced are many teenagers whose intensity reads up after being active in the community of Tuban Literacy. In addition, there are many young people participating in the community of Tuban Literacy activities 


\section{REFERENCES}

Agrawal, A. (2001). Common Property Institutions and Sustainable Governance of Resources. World Devel 29 (10) : 1649-1672.

Aprilia, N.H. (2016). Upaya peningkatan minat dan budaya baca anak jalanan di taman bacaan masyarakat (tbm) rumah singgah anak mandiri yogyakarta. Jurnal Elektronik Mahasiswa PLS. 5(5), 50-60.

Abdurrahman, Mulyono. (2012). Anak Berkesulitan Belajar. Jakarta: Rineka Cipta.

Bourdieu, Pierre. (1986). The Form of Capital : Hand Book Theory and Research in. Sociologi of Education, J.G. Richardson (edt). West Port : Greenwood Press.

Bourdieu, P. (1986). Outline of a Theory of Practive. Cambridge and New York : Cambridge University Press.

Creswell, John W. (2009). Research design: pendekatan kualitatif, kuantitatif, dan mexed. Edisi ketiga. Terjemahan oleh achmad fawaid. 2010. Yogyakarta: Pustaka Pelajar.

Carron, G., Mwiria, K., \& Righa, G. (1989). The functioning and effects of the kenyan literacy program: a view from the local level (research report no. 77). Paris: international institute for educational planning. carr-hill, $\mathrm{r}$ (ed.) 2001. Adult literacy programs in uganda. africa region human development series. Washington: The World Bank.

Coleman J. S. (1988). Social Capital in the Creation of Human Capital. American. Journal of Sociology 94 (supplement): S95-S120

Chaskin, J. Robert. (2001). Building community capacity. New York: Walter De Gruyter, Inc.

Calhoun, C. (1968). Computer technology, large-scale social integration, and the local coommunity. Urban affairs quaterly $22: 329-49$.

Dwiyantari, Sri \& Kaligis, Retor AW. (2015). Penguatan komunitas melalui pemanfaatan modal sosial untuk penanggulangan penyalahgunaan narkoba di masyarakat. INSANI, 2 (2), 43-51

Drajat, Zakiah. (2001). Metodik khusus pengajaran agama islam. Jakarta: Bumi Aksara.

Direktorat Statistik Pendidikan Dan Kesejahteraan Sosial. (2015). Statistik sosial budaya: survey sosial ekonomi nasional 2015. Jakarta: Badan Pust Statitik

Darmawan. (2016). Efektivitas Taman Bacaan Masyarakat (TBM) dalam Meningkatkan Motivasi Membaca Masyarakat di PKBM Ceria. Jurnal Transformasi. 2 (1), 1-7.

Dahal, G.R dan Adhikari, K.P. (2008). Bridging, Linking, and Bonding Social Capital in Collective Action: The case of Kalahan Forest Reserve in Phillippines. Washington D.C., USA, International Food Policy Research Institute (IFPRI)

ELN (2017, 21 Maret). Gerakan Literasi Sekolah Bersambut di Daerah. Kompas. Tersedia: http://edukasi.kompas.com.

Fahrurrozi. (2015). Pendampingan pengembangan budaya baca siswa madrasah tsanawiyah darul ulum. DIMAS, 15(2), 97-114.

Fahrurrozi. (2015). Pengembangan budaya membaca siswa madrasah ibtidaiyah di kota semarang. Dimas, 16 (1), 87-102.

Farida, S. (2012, Mei). Faktor-faktor penyebab keengganan membaca di lingkungan mahasiswa. Seminar Nasional Bahasa, Bandung.

Halbert, K., \& Chigeza, P. (2015). Navigating discourses of cultural literacy in teacher education. Australian Journal Of Teacher Education. Research online. 40(11), 155-168. Doi: 10.14221/ajte.2015v40n11.9

Hernowo (Edt). (2002). Quantum reading: cara cepat dan bermanfaat untuk merangsang munculya potensi membaca. Bandung: MLC.

Habermas, J. (1982). A Reply to my Critics : In Habermas :Critical debates, eds. J. Thompson and D. Held, pp 219-283.Cambridge, MA : MIT Press.

Hidayat, R. (2013). Pedagogi Kritis: Sejarah, Perkembangan dan Pemikiran Jakarta: Rajawali Pers.

Hui, S.K.F., \& Cheung, H.Y. (2015). Cultural literacy and student engagement: the case of technical and vocational education and training (tvet) in hong kong. Journal Of Further And Higher Education, 39(4), 553-578. Diperoleh dari http://www.tandfonline.com/loi/cjfh20

Jencks, C. (1979). The Social Basis of Unselfishness. Philadephia: University of Pennsylvania Press.

Kwame, R. Kavi, S. N. Tackie, B. \& Bugyei, K.A. (2015). "Reading For Pleasure Among Junior High School Students: Case Study Of The Saint Andrew`S Anglican Complex Junior High School, Sekondi”. Library Philosophy And Practice, Vol. 3

Lera, A. Kamalova \& Natal'ya D. Koletvinova (2016). The problem of reading and reading culture improvement of students bachelors of elementary education in modern high institution. International Journal Of Environmental \& Science Education, 11(4), 473-484.

Moleong, Lexy. (2007). Metode Penelitian Kualitatif. Bandung: PT. Remaja Rosdakarya.
Marshall, G. (1998). A Dictionary of sociology. New York: Oxford University Press.

Meinzen-Dick, R. (2004). Methods for Studying Collective Action for Effective Environental Management and Social Learning in Wales. Proceedings of the 9th European IFSA Symposium, 4-7 July 2010, Vienna, Austria.

Mendikbud. (2015). Permendikbud No. 21 Tahun 2015 tentang gerakan pembudayaan karakter di sekolah. Jakarta: Kementerian Pendidikan dan Kebudayaan.

Miller, Bryon. (2014). Collective Action and Rational Choice, Community, and the Limits to Individual Self-Interest. Journal of Economic Geography, Vol. 68,No. 1. Clark Universtity.

Nuryatno, M. Agus. (2011). Mazhab Pendidikan Kritis. Yogyakarta: Resist Book.

Nag, S., Snowling, M.J., \& Asfaha, Y.M. (2016). Classroom literacy practices in low and middle-income countries: an interpretative synthesis of ethnographic studies. Oxford Review Of Education, 42(1), 36-54. Diperoleh dari http://www.tandfonline.com/doi/full/10.1080/03054985.2015.1135115

Ostrom, Elinor. (2002). The Drama of the Commons. Committee on the Human Dimensions of Global Change. Washingon, D.C : Natonal Research Council, National Academy Press.

Olson, M. (1965). The Logic of Collective Action. Cambridge: Harvard University Press.

Penetrasi dan perilaku pengguna internet indonesia. (n.d). diperoleh pada Nopember 22, 2016 dari https://apjii.or.id/content/read/39/264/SurveiInternet-APJII-2016

Permatasari, A. (2015, Juli). Membangun kualitas bangsa dengan budaya literasi. Prosiding Seminar Nasional Bulan Bahasa, Bengkulu.

Prins, E. (2008). Adult literacy education, gender equity and empowerment: Insights from a Freirean-inspired literacy programme. Studies in the Education of Adults. 40(1), 24-39. Received from https://www.researchgate.net/publication/233504672

Putnam, R., R. Leonardi., R. Nanetti. (1993). Making Democracy Work : Civic Traditions in Modern Italy. Princeton: Princeton University Press.

Robinson, Anna. (2014). Literacy and educationfor sustainable development and women's empowerment. Hamburg: UNESCO Institute for Lifelong Learning.

Rahim, Farida. (2008). Pengajaran membaca di sekolah dasar. Jakarta: Bumi Aksara.

Pinto, Ramos. (2006). Social Capital as a Capacity for Collective Action. Cambridge, England: Cambridge Scholar Press.

Syawie, Mochamad. (2007). Peran kelompok sosial dalam penguatan ketahanan sosial (sebuah kajian modal sosial di desa abiansemal, kecamatan abiansemal, kabupaten badung, bali). Jurnal Penelitian dan Pengembangan Kesejahteraan Sosial, 2 (1), 45-51.

Sani, M.A.S., \& Suwanto, S.A. (2018). Pembinaan Minat Baca Masyarakat Melalui Pembangunan Taman Bacaan Masyarakat Desa Kemasan Klepu, Semarang, Jawa Tengah. ANUVA. 2 (2), 165-176.

Siswati. (2010). Minat Membaca pada mahasiswa (studi deskriptif pada mahasiswa fakultas psikologi undip semester i). Jurnal Psikologi Undip. $8(2), 124-134$

Slameto. (2010). Belajar Dan Faktor-Faktor Yang Mempengaruhinya. Jakarta: Rineka Cipta.

Shofatussamawati. (2014). Menumbuhkan minat baca dengan pengenalan perpustakaan pada anak sejak dini. Jurnal Ribraria, 2(1), 46-59.

Setiawan, Dadang. (2016). Dukungan sosial orangtua dalam menumbuhkan minat baca pada siswa kelas viii di smp negeri 3 sewon bantul. Jurnal Kebijakan Pendidikan. 4(5), 395-407.

Suharyan \& Tamba, I.W. (2017). Evaluasi Program Kampung Literasi Dalam Menumbuhkan Minat Baca Masyarakat Di Desa Sesela Kecamatan Gunungsari. Jurnal Transformasi . 3 (2), 1-12.

Soekanto, Soerjono. (2012). Sosiologi suatu pengantar. Jakarta: PT. Rajawali Pers.

Syah, Muhibbin. (2004). Psikologi Pendidika. Bandung: Remaja Rosda Karya.

Sobur, Alex. (2003). Psikologi Umum. Bandung: Pustaka Setia.

Soleman B. Taneko. (1984). Struktur dan Proses Sosial Suatu Pengantar Sosiologi Pembangunan. Jakarta: CV. Rajawali.

Sinclair, Zack, \& Russ, L. (2006). Organization development for social change: an integrated approach to community transformation. Zack Sinclair and Movement Strategy Center.

Sulistyo, Basuki. (1991). Pengantar Ilmu Perpustakaan. Jakarta: Gramedia.

Tanjung, S. (2016, Oktober). Menonton televisi secara cerdas dan kritis melalui metode diet tv sebagai strategi media literacy. Seminar Nasional Dan Gelar Produk, Yogyakarta. 
Triatma, I. N. (2016). Minat baca pada siswa kelas vi sekolah dasar negeri delegan 2 prambanan sleman yogyakarta. E-Jurnal Prodi Teknologi Pendidikan. 5(6), 166-178.

Tilaar, H.A.R. (2002). Membenahi Pendidikan Nasional. Jakarta: PT. Rineka Cipta.

Widyaningrum, L. (2016). Membudayakan literasi berbasis manajemen sekolah (aplikasi, tantangan dan hambatan). DIMAS, 16(1), 125-144.

Wicaksana, Galuh. (2011). Buat anakmu gila membac. Yogyakarta: Buku Biru.
Wenger, Etienne (et.al.). (2002). Cultivating communities of practice: a guide to managing knowledge. Boston: Harvard Business School Press.

World's most literate nations ranked. (n.d). diperoleh pada Nopember 22, 2016 dari http://webcapp.ccsu.edu/?news=1767\&data

Yin, Robert K. (2008). Studi Kasus Desain dan Metode. Terjemahan: M. Djauzi Mudjazir. Jakarta: PT. Rajawali Pers.

Yanto, A., Rodiah, S., \& Lusiana, E. (2016). Model Aktivitas Gerakan Literasi Berbasis Komunitas Di Sudut Baca Soreang. Jurnal Kajian Informasi \& Perpustakaan. 2 (1), 107-118 